\title{
Monocyte count to HDL-cholesterol level ratio on post-operative outcome after coronary Bypass surgery
}

\section{Monosit sayısının HDL-kolesterole oranı ile koroner arter Bypass cerrahisi sonrası dönemdeki sonuçlar}

\author{
Ahmet DOLAPOĞLU ${ }^{1} \oplus$, Eyup AVCI ${ }^{2} \oplus$, Muhammed KIZILGÜL ${ }^{3} \odot$ \\ ${ }^{1}$ Balıkesir Üniversitesi Tıp Fakültesi, Kalp ve Damar Cerrahisi Ana Bilim Dalı, Balıkesir, Türkiye \\ ${ }^{2}$ Balıkesir Üniversitesi Tip Fakültesi, Kardiyoloji Ana Bilim Dalı, Balıkesir, Türkiye \\ ${ }^{3}$ Kilis Devlet Hastanesi, Kilis, Türkiye
}

\begin{abstract}
Objective: The monocyte count to HDL-Cholesterol ratio (MHR) has been used for a prognostic indicator of cardiovascular disease. We aimed to evaluate the association between pre-operative MHR and postoperative outcome in patients undergoing coronary artery bypass graft (CABG) surgery.

Methods: A hundred and fifteen patients with isolated CABG surgery were included in the study. Patient's clinical characteristics, surgical details and postoperative early mortality and morbidities were recorded.

Results: The mean age was $63.46 \pm 9.35$. MHR was slightly higher in patients with previous myocardial infarction (MI) but there was no statistical difference. Although post-operative complications including low cardiac output syndrome, stroke, surgical wound infection, renal failure, venous thromboembolism and pulmonary embolism have been found slightly higher in patients with elevated MHR, there was no statistical difference between groups. There was also no association between MHR and perioperative mortality. In correlation analysis, there was no correlation found between MHR and length of mechanical ventilation times, length of hospital stay.

Conclusion: MHR didn't predict postoperative early mortality and morbidity and didn't affect the postoperative outcome in patients undergoing CABG surgery.
\end{abstract}

Keywords: Monocyte count to HDL-C ratio, cardiovascular disease, coronary artery bypass graft surgery

ÖZ

Amaç: Monosit sayısının HDL-Kolesterole oranı (MHO) kardiyovasküler risk belirteci olarak kullanılmaktadır. Bu çalışmada, koroner arter bypas (KABG) cerrahisi uygulanan hastalarda cerrahi öncesi MHO ile cerrahi sonrası dönemde mortalite ve komplikasyonlar arasındaki ilişkiyi değerlendirmeyi amaçladık.

Yöntem: Çalışmaya izole KABG cerrahisi uygulanan 115 hasta alındı. Hastaların klinik karakteristikleri, cerrahi detayları ve cerrahi sonrası gelişen mortalite ve komplikasyonlara ait veriler kaydedildi.

Bulgular: Ortalama yaş $63,46 \pm 9,35$ idi. Daha önce miyokardiyal infarktüs geçiren hastalarda MHO'da hafif düzeyde artış bulunmasına rağmen, istatistik açıdan anlamlı fark izlenmemiştir. Cerrahi sonrası erken dönemde düşük debi sendromu, inme, böbrek yetmezliği, cerrahi yara infeksiyonu venöz ve pulmoner emboli gibi komplikasyonlar görülen hastalarda MHO'da hafif bir artış izlense de istatistik açıdan anlamlı fark bulunmamıştır. MHO ile perioperative mortalite arasında da ilişki bulunmamıştır. Korelasyon analizinde ise MHO ile mekanik ventilasyon süreleri ile hastanede kalış süreleri arasında korelasyon bulunmamıştır.

Sonuç: İole KABG cerrahisi uygulanan hastalarda cerrahi öncesi MHO değerleri ile cerrahi sonrası erken dönemde mortalite ve morbidite arasında ilişki bulunmamıştır.

Anahtar kelimeler: Monosit sayısının HDL-Kolesterole oranı, kardiyovasküler hastalık, koroner arter bypas greft cerrahisi

Alındığı tarih: 08.09.2018

Kabul tarihi: 20.09 .2018

Yazışma adresi: Yard. Doç. Dr. Ahmet Dolapoğlu, Balıkesir Üniversitesi Tıp Fakültesi, Kalp ve Damar Cerrahisi Ana Bilim Dalı, Balıkesir e-mail: ahmetdolapoglu@yahoo.com

Yazarların ORCID bilgileri:

A.D. 0000-0001-9161-2631

E.A. $0000-0002-7790-8450$

M.K. 0000-0002-8468-9196 


\section{INTRODUCTION}

Monocytes are the largest type of white blood cells and they are one of the most essential components of the innate immune system ${ }^{(1)}$. Roughly 3 to $10 \%$ of white blood cells are monocytes. Circulating monocytes and their differentiated forms play an important role in inflammation but their excessive activation and accumulation develop oxidative stress. It is known that a high level of monocytes can exacerbate some inflammatory diseases such as atherosclerosis ${ }^{(2)}$.

High-density lipoprotein cholesterol (HDL-C) picks up excessive cholesterol in the blood and take it back to the liver where it's broken down and removed from the body ${ }^{(3)}$. On the other hand, HDL-C shows anti-inflammatory and anti-oxidant properties by inhibiting the transmigration of the monocytes. Higher levels of HDL-C are associated with reducing the risk of heart disease ${ }^{(4)}$.

The monocyte count to HDL-C ratio (MHR) has been used for the indicator of inflammation. Recent studies have shown that MHR is indicating the extent of oxidative stress and is used as a prognostic marker for cardiovascular disease ${ }^{(5)}$.

The aim of this study was to assess the association between MHR and postoperative outcome in patients undergoing coronary artery bypass graft (CABG) surgery.

\section{MATERIAL and METHODS}

A hundred and fifteen patients who underwent isolated CABG from August 2017 to May 2018 were included in this study. The study was approved by the ethical committee and informed consent was obtained from all patients. All patients charts were reviewed retrospectively. Clinical characteristics, surgical details, and postoperative outcome were obtained from the patient's charts. Patients who underwent additional cardiovascular surgeries (valvular surgery, aorta surgery, peripheral vascular surgery) and patients with low left ventricular ejection fraction $(<30 \%)$, chronic kidney disease and cardiac rhythm problem were excluded.
All CABG surgeries were performed under general anesthesia with standard median sternotomy and on-pump fashion. Blood samples were obtained from the patients before surgery day for analysis of routine biochemistry and lipid panel. A reference value for monocyte count in our laboratory was $2 \%$ to $10 \%$ of total white blood cells.

The patient's clinical characteristics including age, gender, preoperative monocyte count, HDL-C, creatinine, and blood urea nitrogen (BUN) levels, left ventricular ejection fraction (LVEF); patients comorbidities including diabetes mellitus, hypertension, smoking, chronic pulmonary obstructive disease (COPD), previous myocardial infarction (MI), peripheric arterial disease (PAD); and surgical details including cardiopulmonary bypass (CPB) time and cross-clamp (X-Clamp) time were collected.

Post-operative following outcomes were extracted: low cardiac output syndrome (LCOS) which is post-operative requirement of inotropic agents or intra-aortic balloon pump, renal failure which is requiring dialysis, neurologic deficits (stroke), surgical wound infections, deep venous thrombosis or pulmonary embolism, new-onset cardiac arrhythmias and peri-operative mortality including intra- and post-operative period. Post-operative length of stay (LOS) in intensive care units (ICU) and overall, and length of postoperative mechanical ventilation times were also calculated.

The primary endpoint of our study was an association between pre-operative MHR and postoperative outcomes.

All statistical analyses were performed by using the JMP 13.0.1 software (SAS Institute, Cary, NC, USA). Quantitative data are expressed as the mean \pm standard deviation or counts and proportions for categorical data. Normality of distribution was examined by using the Kolmogorov-Smirnov or ShapiroWilk W test. Student's t-test was used for normally distributed continuous variables and the MannWhitney U test for those that did not normally distributed. Pearson's and Spearman's correlation were used for assessment of correlations. A p-value lower than 0.05 was accepted as statistically significant. 


\section{RESULTS}

A total of 115 patients, including 31 women, with a mean age of $63.46 \pm 9.35$ years, were enrolled. Five patients died in the postoperative early period. Patient's clinical characteristics are presented in Table 1. MHR was slightly higher in patients with previous MI but there were no statistically difference (p:0.6906). MHR was similar between patients with diabetes, hypertension, PAD, COPD, smoking, and patients without. Although post-operative complications including LCOS, stroke, surgical wound infection, renal failure, venous thromboembolism and pulmonary embolism have been found slightly higher in patients with elevated MHR, there was no statistical difference. There was no association between MHR and peri-operative mortality (Table 2). İn correlation analysis, no correlation was found between

Table 1. Association between patients clinical characteristics and MHR.

\begin{tabular}{|c|c|c|c|c|c|}
\hline & \multicolumn{4}{|c|}{ MHR } & \multirow[b]{3}{*}{$\mathbf{p}$} \\
\hline & \multicolumn{2}{|c|}{ Complication (-) } & \multicolumn{2}{|c|}{ Complication (+) } & \\
\hline & Median & $\begin{array}{c}\text { Interquartile } \\
\text { Range }\end{array}$ & Median & $\begin{array}{c}\text { Interquartile } \\
\text { Range }\end{array}$ & \\
\hline DM & 16.77 & 6.27 & 16.41 & 8.535 & 0.9358 \\
\hline HT & 17.18 & 7.837 & 15.67 & 6.41 & 0.2647 \\
\hline COPD & 16.68 & 7.215 & 14.7 & 6.24 & 0.3165 \\
\hline Smoking & 16.68 & 6.888 & 16.41 & 7.1 & 0.2279 \\
\hline Previous MI & 15.92 & 6.915 & 17.54 & 8.443 & 0.6906 \\
\hline PAD & 16.59 & 6.54 & 15.11 & 9.14 & 0.211 \\
\hline
\end{tabular}

Table 2. Association between post-operative mortality-morbidity and MHR.

\begin{tabular}{|c|c|c|c|c|c|}
\hline & \multicolumn{4}{|c|}{ MHR } & \multirow[b]{3}{*}{$\mathbf{p}$} \\
\hline & \multicolumn{2}{|c|}{ Complication (-) } & \multicolumn{2}{|c|}{ Complication (+) } & \\
\hline & Median & $\begin{array}{c}\text { Interquartile } \\
\text { Range }\end{array}$ & Median & $\begin{array}{c}\text { Interquartile } \\
\text { Range }\end{array}$ & \\
\hline $\begin{array}{l}\text { Mortality- } \\
\text { Peri-operative }\end{array}$ & 16.46 & 7.005 & 17.42 & 19.51 & 0.3764 \\
\hline Inotropy & 15.85 & 7.56 & 17.825 & 6.5 & 0.1785 \\
\hline Stroke & 16.42 & 6.935 & 22.495 & 1.09 & 0.0642 \\
\hline Renal Failure & 16.42 & 7.25 & 17.94 & 5.615 & 0.8011 \\
\hline Wound infection & 16.41 & 7.11 & 18.035 & 6.4 & 0.3145 \\
\hline Arrhythmia & 15.76 & 6.482 & 18.56 & 5.298 & 0.0894 \\
\hline $\begin{array}{l}\text { Pulmonary- } \\
\text { venous } \\
\text { thrombosis }\end{array}$ & 16.415 & 7.005 & 17.61 & 8.92 & 0.6167 \\
\hline
\end{tabular}

MHR and LVEF, X-Clamp time, mechanical ventilation times, LOS-ICU and LOS-overall, except for CBP time (p:0.0405) (Table 3).

Table 3. Correlation analysis.

\begin{tabular}{lcc}
\hline & Correlation Coefficient & p-value \\
\hline LVEF & 0.0967 & 0.304 \\
CPB time & -0.1914 & 0.0405 \\
X Clamp Time & -0.0914 & 0.3315 \\
LOS-ICU & 0.1061 & 0.2589 \\
LOS-Overall & 0.0371 & 0.6942 \\
MV time & 0.1136 & 0.2266 \\
\end{tabular}

\section{DISCUSSION}

Our aim was to investigate the correlation between preoperative MHR and postoperative mortality, morbidity, and outcomes in patients undergoing CABG.

Our findings revealed that MHR was not correlated with postoperative mortality and morbidity such as LCOS, stroke, surgical wound infection, renal failure, venous thromboembolism and pulmonary embolism. This study also showed us that MHR doesn't affect the postoperative outcome.

Monocytes are distinct types of leukocyte and they migrate into the tissue macrophages. They interact with platelets and endothelium and thus initiate inflammation. The activation of monocytes is a key process at the beginning of atherosclerosis. Previous studies have shown that monocyte count was related to predicting coronary artery disease ${ }^{(6,7)}$.

HDL-C achieves anti-oxidant, anti-inflammatory and antiplatelet effects via several pathways, including reducing the expression of endothelial adhesion molecules and increasing reverse transport of oxidized molecules. HDL-C also inhibits monocyte activities and blocks the transformation of monocytes to macrophages, which decrease inflammation. As a consequence, integrating these two measurements as MHR can represent the inflammatory process.

The relationship between MHR and cardiovascular disease (CVD) risk estimation has been evaluated in previous studies. Association between higher MHR and risk of CVD in chronic renal failure has been shown first by Kanbay et al. ${ }^{(8)}$. Canpolat et al. 
(9) reported that in ST elevation MI (STEMI) MHR was related to increased adverse cardiac events and mortality following the coronary angiographic intervention. Cetin et al. ${ }^{(10)}$ found that MHR could predict stent thrombosis following angiographic intervention for STEMI.

We found a couple of studies which is investigating MHR and postoperative morbidity after CABG surgery. A study which was reported by Tekkesin et al. ${ }^{(11)}$ showed that preoperative MHR were significantly higher in patients with postoperative atrial fibrillation. Another study which was reported by Akboga et al. ${ }^{(12)}$ showed that elevated MHR is associated with saphenous vein occlusion after CABG surgery.

We believe that this is the first study to evaluate the relationship between the MHR and postoperative outcomes including mortality and morbidities with many aspects after CABG surgery.

Although MHR has been found slightly elevated in patients with post-operative complications, the association between MHR and the postoperative outcome was nor statistically significant.

The findings of our study might be explained by each of our patients possibly being in the different severity of the atherosclerotic disease. The study had some limitations. This is a single-center study with small sample size; measurement of serum HD-CL and monocyte count at once may be insufficient to use as a parameter; the history of statin use was not known which may possibly affect HDL-C levels. Additionally other inflamation markers such as C-Reactive Protein, sedimantation and high sensitive C-Reactive Protein didn't include into the study due to lack of data, if we could compire MHR with other inflamation markers it would be more helpful to interpretation of meaning of the preoperative MHR.

\section{CONCLUSION}

In conclusion, the MHR didn't predict increase post-operative early mortality and morbidity and didn't affect the postoperative outcome in patients undergoing isolated CABG. Nevertheless, there is a need for studies investigating MHR and postoperative outcomes in order to reduce the risk of surgery.

\section{REFERENCES}

1. Ancuta P, Wang J, Gabuzda D. CD16+ monocytes produce IL-6, CCL2, and matrix metalloproteinase-9 upon interaction with CX3CL1-expressing endothelial cells. J Leukoc Biol. 2006;80:1156-64. https://doi.org/10.1189/jlb.0206125

2. Takahashi K, Takeya M, Sakashita N. Multifunctional roles of macrophages in the development and progression of atherosclerosis in humans and experimental animals. Med Electron Microsc. 2002;35(4):179-203.

https://doi.org/10.1007/s007950200023

3. Barter PJ, Baker PW, Rye KA. Effect of high-density lipoproteins on the expression of adhesion molecules in endothelial cells. Curr Opin Lipidol. 2002;13:285-8. https://doi.org/10.1097/00041433-200206000-00008

4. Murphy AJ, Woollard KJ, Hoang A, Mukhamedova N, Stirzaker RA, McCormick SPA, et al. High-density lipoprotein reduces the human monocyte inflammatory response. Arterioscler Thromb Vasc Biol. 2008;28(11):2071-7. https://doi.org/10.1161/ATVBAHA.108.168690

5. Zhang Y, Li S, Guo Y-L, Wu N-Q, Zhu C-G, Gao Y, et al. Is monocyte to HDL ratio superior to monocyte count in predicting the cardiovascular outcomes: evidence from a large cohort of Chinese patients undergoing coronary angiography. Ann Med. 2016;48(5):305-12. https://doi.org/10.3109/07853890.2016.1168935

6. Olivares R, Ducimetière P, Claude JR. Monocyte count: a risk factor for coronary heart disease? Am J Epidemiol [Internet]. 1993;137(1):49-53. https://doi.org/10.1093/oxfordjournals.aje.a116601

7. Gratchev A, Sobenin I, Orekhov A, Kzhyshkowska J. Monocytes as a diagnostic marker of cardiovascular diseases. Immunobiology. 2012;217(5):476-82 . https://doi.org/10.1016/j.imbio.2012.01.008

8. Kanbay M, Solak Y, Unal HU, Kurt YG, Gok M, Cetinkaya $\mathrm{H}$, et al. Monocyte count/HDL cholesterol ratio and cardiovascular events in patients with chronic kidney disease. Int Urol Nephrol. 2014;46(8):1619-25. https://doi.org/10.1007/s11255-014-0730-1

9. Canpolat U, Çetin EH, Cetin S, Aydin S, Akboga MK, Yayla C, et al. Association of Monocyte-to-HDL Cholesterol Ratio with Slow Coronary Flow is Linked to Systemic Inflammation. Clin Appl Thromb. 2016;22(5):476-82. https://doi.org/10.1177/1076029615594002

10. Cetin MS, Ozcan Cetin EH, Kalender E, Aydin S, Topaloglu $\mathrm{S}$, Kisacik HL, et al. Monocyte to HDL Cholesterol Ratio Predicts Coronary Artery Disease Severity and Future Major Cardiovascular Adverse Events in Acute Coronary Syndrome. Hear Lung Circ. 2016;25(11):1077-86. https://doi.org/10.1016/j.hlc.2016.02.023

11. Tekkesin AI, Hayiroglu MI, Zehir R, Turkkan C, Keskin M, et al. The use of monocyte to HDL ratio to predict postoperative atrial fibrillation after aortocoronary bypass graft surgery. North Clin Istanb. 2017;4(2):145-50.

12. Akboga MK, Yayla C, Balci KG, Ozeke O, Maden O et al.Relationship between Serum Albumin Level and Monocyteto-High-Density Lipoprotein Cholesterol Ratio with Saphenous Vein Graft Disease in Coronary Bypass.Thorac Cardiovasc Surg. 2017 Jun;65(4):315-21. https://doi.org/10.1055/s-0036-1582260 